\title{
Bombyx mori hemocyte extract has anti-inflammatory effects on human phorbol myristate acetate-differentiated THP-1 cells via TLR4-mediated suppression of the NF- $\kappa \mathrm{B}$ signaling pathway
}

\author{
YOUNG IL KIM $^{1 *}$, KWANG HO CHOI ${ }^{2 *}$, SEONG RYUL KIM $^{2}$, TAE-WON GOO ${ }^{3}$ and SEUNG-WON PARK ${ }^{4}$ \\ ${ }^{1}$ Medical Science Research Institute, Kyung Hee University Medical Center, Seoul 02447; \\ ${ }^{2}$ Sericultural and Apicultural Materials Division, National Academy of Agricultural Science, RDA, Wanju, \\ Jeollabuk 55365; ${ }^{3}$ Department of Biochemistry, Dongguk University College of Medicine, Gyeongju, Gyeongsangbuk 38066; \\ ${ }^{4}$ Department of Biotechnology, Catholic University of Daegu, Gyeongsan, Gyeongsangbuk 38430, Republic of Korea
}

Received December 5, 2016; Accepted May 11, 2017

DOI: $10.3892 / \mathrm{mmr} .2017 .7087$

\begin{abstract}
Hemolymph is the circulating fluid of insects and is a key component of their immune system. However, little is known concerning hemocyte identification, development, differentiation and related cellular immune responses. The present study aimed to determine whether a hemocyte extract prepared from Bombyx mori larvae had anti-inflammatory effects; THP-1 (a human monocytic leukemia cell line) cells that had been differentiated into macrophage-like cells by treatment with phorbol myristate acetate (PMA) were used. THP-1 cells were cultured with different concentrations of a $B$. mori hemocyte extract prior to exposure to lipopolysaccharide (LPS) to induce an inflammatory response. The effects of the $B$. mori hemocyte extract on anti-inflammatory pathways were determined using reverse transcription-quantitative polymerase chain reaction and western blotting to assess the expression of pro-inflammatory molecules. The B. mor $i$ hemocyte extract inhibited the LPS-induced mRNA expression of Toll-like receptor 4 in addition to LPS-induced interleukin (IL)-1 $\beta$, IL-6, IL- 8 and tumor necrosis factor- $\alpha$. Treatment of PMA-differentiated THP-1 cells with $B$. mor hemocyte extract also inhibited inducible nitric oxide synthase and cyclooxygenase-2 transcription and translation. Nuclear factor- $\kappa \mathrm{B}$ activation and phosphorylation also decreased. Further in-depth functional studies are required to understand the mechanism underlying the anti-inflammatory effects of silkworm hemocyte extract.
\end{abstract}

Correspondence to: Professor Seung-Won Park, Department of Biotechnology, Catholic University of Daegu, 13-13 Haynag, Hayang, Gyeongsan, Gyeongsangbuk 38430, Republic of Korea E-mail:microsw@cu.ac.kr

${ }^{*}$ Contributed equally

Key words: Bombyx mori, cytokine, hemocyte, nuclear factor- $\kappa \mathrm{B}$ pathway, THP-1 cell, Toll-like receptor 4

\section{Introduction}

The silkworm, Bombyx mori, is considered to have been domesticated from the wild silkworm, Bombyx mandarina, $\sim 5,000-10,000$ years ago and is a typical Lepidopteran insect $(1,2)$. In the silkworm hemolymph, there are five types of circulating hemocytes; prohemocytes, granulocytes, plasmatocytes, spherulocytes and oenocytoids, all of which are directly or indirectly involved in humoral and cellular immunity (3). Hemocytes are a key component of insect immunity (3-6). Insects possess an innate immune system composed of cellular and humoral mechanisms that respond to invasion by microorganisms (2). The humoral immune response includes the production of antimicrobial peptides (AMPs) and pro-phenoloxidase (PPO) (3-10). AMPs are a particularly important component of insect immunity and are primarily produced by hemocytes and fat bodies to combat invading microorganisms $(3,11-18)$.

The inflammation process is mainly associated with the response of the host organism to exogenous pathogens in addition to the response to bodily injury (19-21). Macrophages serve a critical role in the initiation and propagation of inflammatory responses by releasing pro-inflammatory mediators, including nitric oxide (NO), prostaglandin E2 (PGE2) and cytokines that then orchestrate the inflammatory response (22-24). Therefore, the amount of pro-inflammatory mediators and cytokines reflects the degree of inflammation and provides information that can help illuminate the effect of pharmacological agents on the inflammatory process (6). Lipopolysaccharide, (LPS) isolated from gram-negative bacterial cell walls, has been identified to be one of the most potent activators of the immune response and it induces the expression of pro-inflammatory cytokines in animals and humans (25-28). Of relevance to the present study, previous studies have demonstrated that LPS can stimulate macrophages, in addition to astrocytes, to increases production of NO, tumor necrosis factor (TNF)- $\alpha$, cyclooxygenase (COX)-2 and interleukin (IL)-1 $\beta(25,29,30)$.

Macrophages are activated following binding of LPS to Toll-like receptor (TLR) 4. LPS increases the secretion of pro-inflammatory mediators and cytokines to promote the 
inflammatory response $(22,31,32)$. TLR4 is expressed on myeloid-derived cells, including macrophages and dendritic cells, in addition to certain epithelial and endothelial cells, and is an essential component of the innate immune response $(33,34)$. The LPS-initiated signaling cascade leads to activation of the mitogen-activated protein kinase (MAPK) and nuclear factor (NF)- $\mathrm{kB}$ signaling pathways in a myeloid differentiation factor $(\mathrm{MyD})$ 88-dependent or MyD88-independent manner $(22,35,36)$. Activation of TLR4 involves multiple co-receptors, including lipopolysaccharide-binding protein, myeloid differentiation protein-2 (MD-2) and cluster of differentiation 14 . These co-receptors mediate ligation and transfer of LPS to TLR4 $(33,37)$. This ligation induces TLR4 dimerization and activates an MyD88-dependent early response signaling pathway that results in the production of pro-inflammatory cytokines including TNF- $\alpha$, IL-1 $\beta$ and IL- $6(33,38)$.

The current study aimed to determine whether a hemocyte extract prepared from B. mori larvae has anti-inflammatory effects. To establish an immune response, human THP-1 cells that had been differentiated into macrophage-like cells by treatment with phorbol myristate acetate (PMA) and which were then stimulated with LPS were used. The inhibitory properties of the hemocyte extract from $B$. mori on the LPS-stimulated inflammatory response in these THP-1 cells, the cytotoxic effects of the extract on THP-1 cells and the effects of the extract on the LPS-induced production of cytokines, including IL- 6 and TNF- $\alpha$, were investigated.

\section{Materials and methods}

Silkworm collection and cell culture. The 3 day (fifth instar) larvae of B. mori (Baekokjam, Jam 123xJam 124) used in the present study were housed at the National Academy of Agricultural Science (Republic of Korea). The silkworms were reared on fresh mulberry leaves at $25^{\circ} \mathrm{C}, 65-75 \%$ relative humidity, using a 12-h light/dark cycle. Fifth-instar larvae were dissected to collect the hemocytes. The samples were immediately frozen and stored in liquid nitrogen. The extracted samples were freeze-dried using an FD-1 freeze dryer (Eyela; Tokyo Rikakikai Co., Ltd., Tokyo, Japan) and stored at $4^{\circ} \mathrm{C}$ in a vacuum container until further use. The THP-1 human monocytic leukemia cell line was supplied by the Korean Cell Line Bank (Seoul, Korea). Cells were cultured in RPMI 1640 medium containing $10 \%$ fetal bovine serum and antibiotics (all from Gibco; Thermo Fisher Scientific, Inc., Waltham, MA, USA). For differentiation into macrophages, THP-1 cells were incubated at $37^{\circ} \mathrm{C}$ in a humidified $5 \% \mathrm{CO}_{2}$ atmosphere and treated with 100 nM PMA (Sigma-Aldrich; Merck KGaA, Darmstadt, Germany) for 72 h. Following differentiation, non-attached cells were removed by aspiration. The adherent macrophages were then washed three times with RPMI 1640 medium and incubated in cell culture medium at $37^{\circ} \mathrm{C}$.

Cell viability assay. Cells were seeded at a density of $1 \times 10^{4}$ cells/well in 96-well plates and incubated with various concentrations $(0,50,100,200,300,400$ and $500 \mathrm{ppm})$ of freeze-dried hemocyte extract at $37^{\circ} \mathrm{C}$ for $24 \mathrm{~h}$. Cell numbers were measured with the Cell Titer 96 Aqueous One solution which contained phenazine ethosulfate (PES) and 3- (4,5-dimet hyl-2-yl)-5-(3-carboxymethoxyphenyl)-2-(4-sulfophenyl) -2H- tetrazolium, inner salt (MTS; Promega Corporation, Madison, WI, USA). Absorbance was determined at $490 \mathrm{~nm}$, with background subtraction at $650 \mathrm{~nm}$ using an Emax microplate reader (Molecular Devices, LLC, Sunnyvale, CA, USA).

Treatment with LPS and freeze-dried hemocytes. THP-1 cells were pre-treated for $2 \mathrm{~h}$ in serum-free medium with freeze-dried hemocyte extract and then incubated with LPS $(1 \mu \mathrm{g} / \mathrm{ml})$ for $4 \mathrm{~h}$ (for mRNA expression) or $20 \mathrm{~h}$ (for protein expression). At each time point, total RNA and protein were isolated from the cultured THP-1 cells.

$c D N A$ synthesis and reverse transcription-quantitative polymerase chain reaction ( $R T-q P C R)$. Total RNA was purified from cultured cells using TRIzol reagent (Invitrogen; Thermo Fisher Scientific, Inc.) according to the manufacturer's protocol. For first-strand cDNA synthesis, $1 \mu \mathrm{g}$ total RNA was transcribed to cDNA using a reverse-transcription system with random hexamers (A3500; Promega Corporation) according to the manufacturer's protocol. RT-qPCR was performed on a StepOnePlus Real-Time PCR system with Power SYBR-Green PCR Master Mix (Applied Biosystems; Thermo Fisher Scientific, Inc.). The PCR was performed with $1 \mu 1 \mathrm{cDNA}$ in a $20 \mu 1$ reaction mixture comprising $10 \mu 1$ Power SYBR Green PCR Master Mix, $2 \mu 1$ primers and $7 \mu$ PCR-grade water. The PCR program was as follows: A denaturation step at $95^{\circ} \mathrm{C}$ for $10 \mathrm{~min}, 40$ cycles each of $95^{\circ} \mathrm{C}$ for $15 \mathrm{sec}$ and $60^{\circ} \mathrm{C}$ for $1 \mathrm{~min}$. Quantification of gene expression data was calculated using the $2^{-\Delta \Delta \mathrm{Cq}}$ method the crossing point of the target genes with $\beta$-actin was calculated using the formula 2-(target gene- $\beta$-actin) and the relative amounts were quantified (39). The sequences of the gene-specific primers used (Bioneer Corporation, Daejeon, Korea) are listed in Table I.

Western blot analysis. THP-1 cells were collected and washed with cold phosphate-buffered saline (Welgene, Daegu, Korea) and lysed using lysis buffer (20 mM Tris- $\mathrm{HCl} \mathrm{pH} \mathrm{7.5,} 150 \mathrm{mM}$ $\mathrm{NaCl}, 1 \mathrm{mM} \mathrm{Na}{ }_{2}$ EDTA, $1 \mathrm{mM}$ ethylene glycol tetra-acetic acid, $1 \%$ Triton, $2.5 \mathrm{mM}$ sodium pyrophosphate, $1 \mathrm{mM}$ $\beta$-glycerophosphate and $1 \mathrm{mM} \mathrm{Na}_{3} \mathrm{VO}_{4}$, supplemented with $1 \mu \mathrm{g} / \mathrm{ml}$ leupeptin and $1 \mathrm{mM}$ phenylmethylsulfonyl fluoride; Cell Signaling Technology, Inc., Danvers, MA, USA). The protein concentration was determined using a bicinchoninic acid protein assay (Thermo Fisher Scientific, Inc.) according to the manufacturer's protocol. A total of $30 \mu \mathrm{g}$ protein (per sample) was fractionated by $12 \%$ sodium dodecyl sulfate-polyacrylamide gel electrophoresis and transferred by electrophoresis onto nitrocellulose membranes. The membranes were blocked with 5\% nonfat dry milk for $1 \mathrm{~h}$ at room temperature and subsequently incubated overnight at $4^{\circ} \mathrm{C}$ with antibodies against inducible nitric oxide synthase (iNOS; cat. no. AB5382; Chemicon; EMD Millipore, Billerica, MA, USA), COX-2 (cat. no. SC-19999; Santa Cruz Biotechnology, Inc., Dallas, TX, USA), NF-кB p65 (cat. no. 8242; Cell Signaling Technology, Inc.), phosphorylated-NF- $\mathrm{B}$ p65 (cat. no. 3031; Cell Signaling Technology, Inc.) and $\beta$-actin (A5441; Sigma-Aldrich; Merck KGaA), diluted 1:1,000 with Tris-buffered saline containing $0.05 \%$ Tween 20 (TBST). Following washing with TBST for $1 \mathrm{~h}$, the membranes were incubated for $1 \mathrm{~h}$ at room temperature with anti-rabbit 
Table I. Primer pairs used in reverse transcription-quantitative polymerase chain reaction.

\begin{tabular}{|c|c|c|}
\hline Name & Sequence $\left(5^{\prime}-3^{\prime}\right)$ & Product length (bp) \\
\hline \multirow[t]{2}{*}{ TLR2 } & F, TCTCCCATTTCCGTCTTTTT & \\
\hline & R, GGTCTTGGTGTTCATTATCTTC & 125 \\
\hline \multirow[t]{2}{*}{ TLR4 } & F, GAAGCTGGTGGCTGTGGA & \\
\hline & R, TGATGTAGAACCCGCAAG & 213 \\
\hline \multirow[t]{2}{*}{ iNOS } & F, TGGATGCAACCCCATTGTC & \\
\hline & R, CCCGCTGCCCCAGTTT & 59 \\
\hline \multirow[t]{2}{*}{$\mathrm{COX}-2$} & F, CAAATCCTTGCTGTTCCCACCCAT & \\
\hline & R, GTGCACTGTGTTTGGAGTGGGTTT & 173 \\
\hline \multirow[t]{2}{*}{ IL-1ß } & F, TGATGGCTTATTACAGTGGCAATG & \\
\hline & R, GTAGTGGTGGTCGGAGATTCG & 140 \\
\hline \multirow[t]{2}{*}{ IL-6 } & F, GTGTTGCCTGCTGCCTTC & \\
\hline & R, AGTGCCTCTTTGCTGCTTTC & 194 \\
\hline \multirow[t]{2}{*}{ IL-8 } & F, GACATACTCCAААССТTТССАС & \\
\hline & R, CTTCTCCACAАСССТСТGC & 160 \\
\hline \multirow[t]{2}{*}{$\mathrm{TNF}-\alpha$} & F, ATCTTCTCGAACCCCGAGTG & \\
\hline & R, GGGTTTGCTACAACATGGGC & 51 \\
\hline \multirow[t]{2}{*}{$\beta$-actin } & F, GCGAGAAGATGACCCAGATC & \\
\hline & R, GGATAGCACAGCCTGGATAG & 77 \\
\hline
\end{tabular}

TLR, toll-like receptor; iNOS, inducible nitric oxide synthase; COX, cyclooxygenase; IL, interleukin; TNF, tumor necrosis factor; F, forward; $\mathrm{R}$, reverse.

(cat. no. 7074; Cell Signaling Technology, Inc.) and anti-mouse (cat. no. 7076; Cell Signaling Technology, Inc.) horseradish peroxidase-conjugated secondary antibodies diluted 1:2,500 in TBST. The membranes were subsequently washed with TBST for $1 \mathrm{~h}$ and proteins were detected using an enhanced chemiluminescence kit (Santa Cruz Biotechnology, Inc.). Protein expression was analyzed using a Davinch-Chemi ${ }^{\mathrm{TM}}$ Chemiluminescence Imaging System (Chemi Fluoro Imager M8 version, CAS-400 Chemi-DOC Image Analyzer; Davinch-K Co. Ltd., Seoul, Korea). Protein band densities were measured using ImageJ analysis software (ImageJ; version 1.44; National Institutes of Health, Bethesda, MD, USA).

Statistical analysis. Data are expressed as the mean \pm standard error. Data were compared by one-way analysis of variance and Tukey's post hoc test. Statistical analyses were performed using the GraphPad Prism 5 software (GraphPad Software Inc., San Diego, USA). P $<0.05$ was considered to indicate a statistically significant difference.

\section{Results}

B. mori hemocyte extract does not affect THP-1 cell proliferation. Cells were treated with various concentrations $(0,50,100,200,300,400$ and 500 ppm) of B. mori hemocyte extract for $24 \mathrm{~h}$ and cell proliferation was examined using a PES/MTS-based solution. As demonstrated in Fig. 1, the $B$. mori hemocyte extract did not affect the cell proliferation rate (cell viability).

B. mori hemocyte extract inhibits LPS-induced increase in TLR4 mRNA expression in THP-1 cells. To investigate the

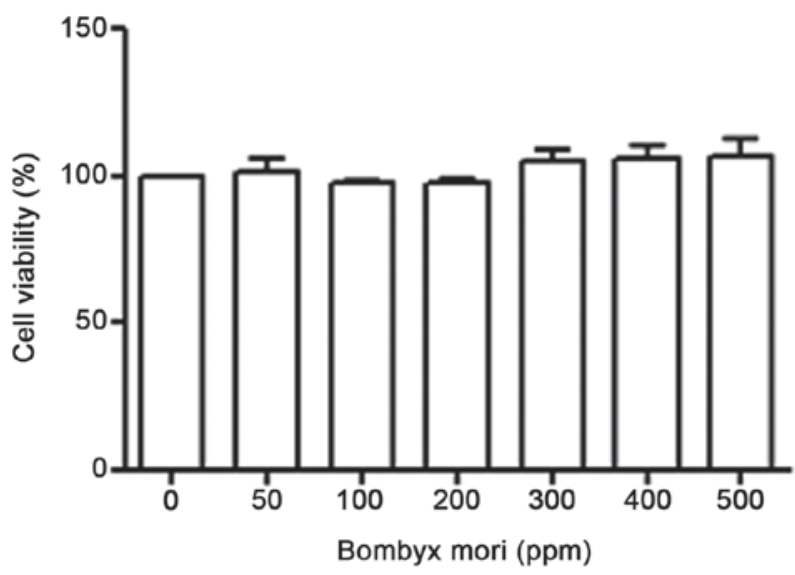

Figure 1. Effects of Bombyx mori hemocyte extract on the proliferation of THP-1 cells. THP-1 cells were treated with various concentrations of freeze-dried hemocyte extract $(0,50,100,200,300,400$ and $500 \mathrm{ppm})$ for $24 \mathrm{~h}$. Cell viability was then determined with a PES, phenazine ethosulfate/MTS, 3-(4,5-dimethyl-2-yl)-5-(3-carboxymethoxyphenyl)2-(4-sulfophenyl) -2H-tetrazolium, inner salt-based assay. The data represent the mean \pm standard error of three independent experiments performed in triplicate.

effect of B. mori hemocyte extract on TLR2 and TLR4 expression in THP-1 cells, mRNA expression was measured using RT-qPCR. Following LPS stimulation, TLR4 mRNA expression was greater compared with control THP-1 cells. B. mori hemocyte extract suppressed the LPS-induced increase in the mRNA expression of TLR4 but not of TLR2 (Fig. 2).

B. mori hemocyte extract inhibits LPS-induced iNOS and COX-2 expression. To examine the effects of the $B$. mori 

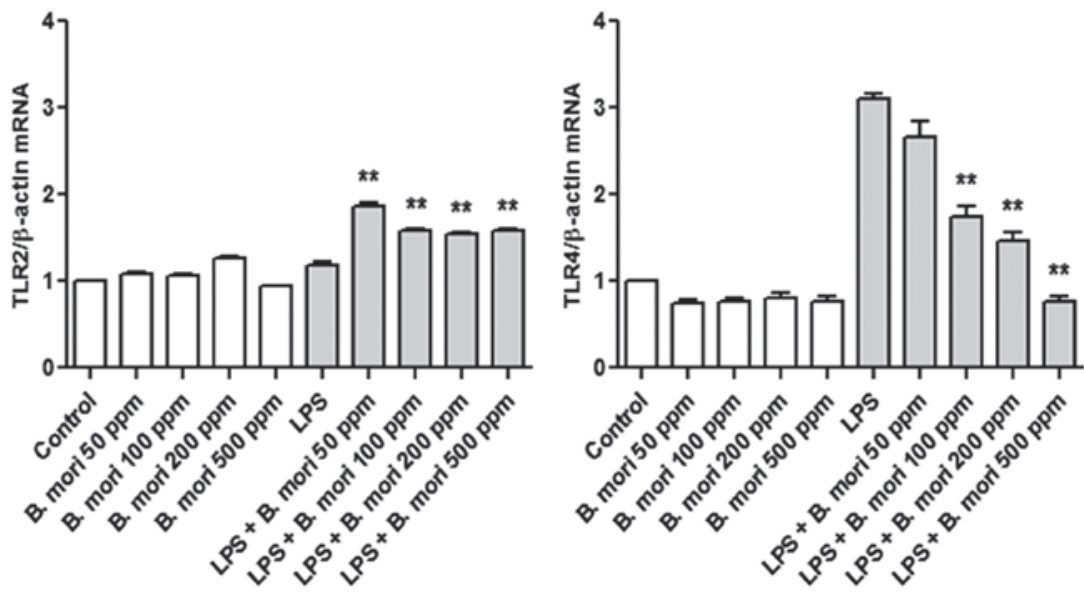

Figure 2. Effects of B. mori hemocyte extract on the LPS-induced increase in TLR mRNA expression in THP-1 cells. Cells were incubated for $2 \mathrm{~h}$ in serum-free medium containing different concentrations of a freeze-dried hemocyte extract $(0,50,100,200$ and $500 \mathrm{ppm})$ and were either left unstimulated or were stimulated with LPS $(1 \mu \mathrm{g} / \mathrm{ml})$ for $4 \mathrm{~h}$. The mRNA levels of TLR2 and TLR4 were measured by real-time quantitative polymerase chain reaction and normalized to $\beta$-actin. The data represent the mean \pm standard error of three independent samples. ${ }^{* *} \mathrm{P}<0.01 \mathrm{vs}$. stimulation with LPS alone. LPS, lipopolysaccharide; TLR, Toll-like receptor; B. mori, Bombyx mori.
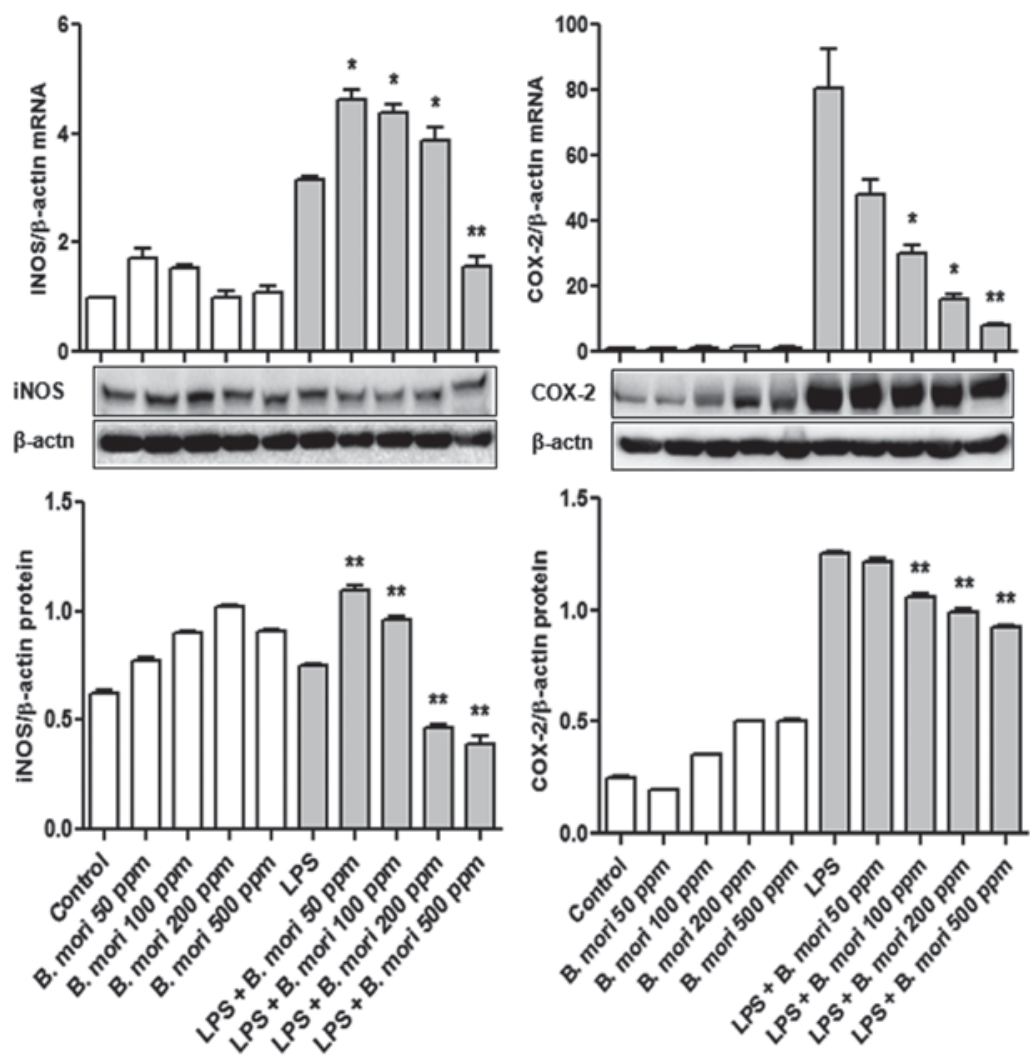

Figure 3. Effects of B. mori hemocyte extract on the expression of iNOS and COX-2 in THP-1 cells. Cells were cultured with different concentrations of freeze-dried hemocyte extract $(0,50,100,200$ and $500 \mathrm{ppm})$ for $2 \mathrm{~h}$ and were then either left unstimulated or were stimulated with LPS $(1 \mu \mathrm{g} / \mathrm{ml})$ for $4 \mathrm{~h}$ (for mRNA expression) or for $20 \mathrm{~h}$ (for protein expression). $\beta$-actin served as an internal control. The data are expressed the mean \pm standard error of three independent samples. "P<0.05 and ${ }^{* *} \mathrm{P}<0.01$ vs. stimulation with LPS alone. iNOS, inducible nitric oxide synthase; COX, cyclooxygenase; LPS, lipopolysaccharide; B. mori, Bombyx mori.

hemocyte extract on iNOS and COX-2 mRNA and protein expression levels, THP-1 cells were treated with various concentrations of hemocyte extract and LPS. iNOS and COX-2 mRNA and protein expression were measured using RT-qPCR and western blot analyses, respectively. Treatment with the hemocyte extract significantly suppressed LPS-induced upregulated iNOS mRNA expression at all tested concentrations $(\mathrm{P}<0.01)$ and iNOS protein expression at $0,50,100$, 200 and 500 ppm of hemocyte extract $(\mathrm{P}<0.05$ and $\mathrm{P}<0.01)$, compared with the control. In particular, at $500 \mathrm{ppm}$ of $B$. mori hemocyte extract, $\mathrm{COX}-2$ transcription and translation were significantly lower than the control $(\mathrm{P}<0.01$; Fig. 3$)$. 

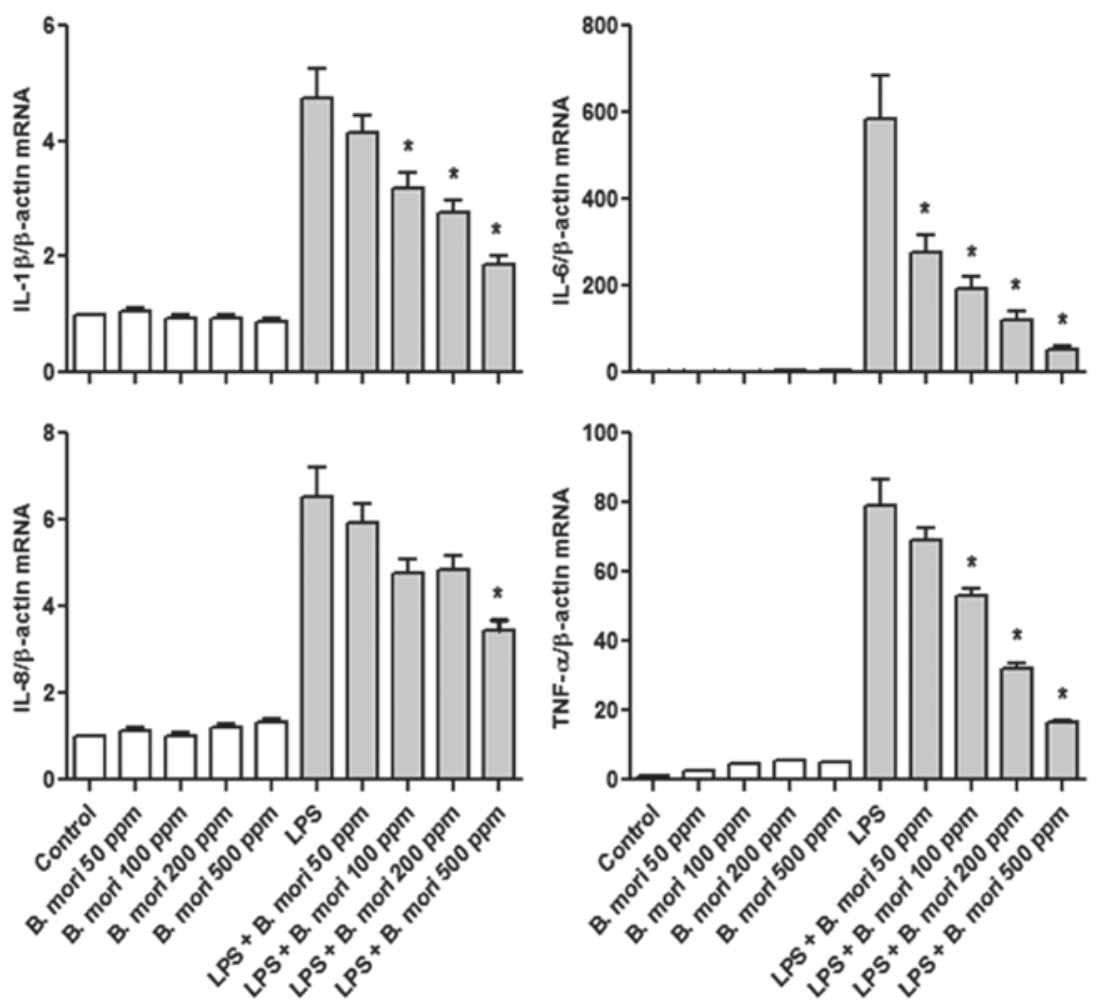

Figure 4. Effects of B. mori hemocyte extract on the LPS-induced increase in cytokine mRNA expression in THP-1 cells. Cells were treated for $2 \mathrm{~h}$ with freeze-dried hemocyte extract $(0,50,100,200$ and $500 \mathrm{ppm})$ and were either left untreated or were treated with LPS $(1 \mu \mathrm{g} / \mathrm{ml})$ for $4 \mathrm{~h}$. The mRNA levels of IL-1 $\beta$, IL-6, IL-8 and TNF- $\alpha$ were measured by reverse transcription-quantitative polymerase chain reaction and normalized to $\beta$-actin. The data represent the mean \pm standard error of the mean values of three independent samples. " $\mathrm{P}<0.05$ vs. stimulation with LPS alone. LPS, lipopolysaccharide; IL, interleukin; TNF, tumor necrosis factor; B. mori, Bombyx mori.
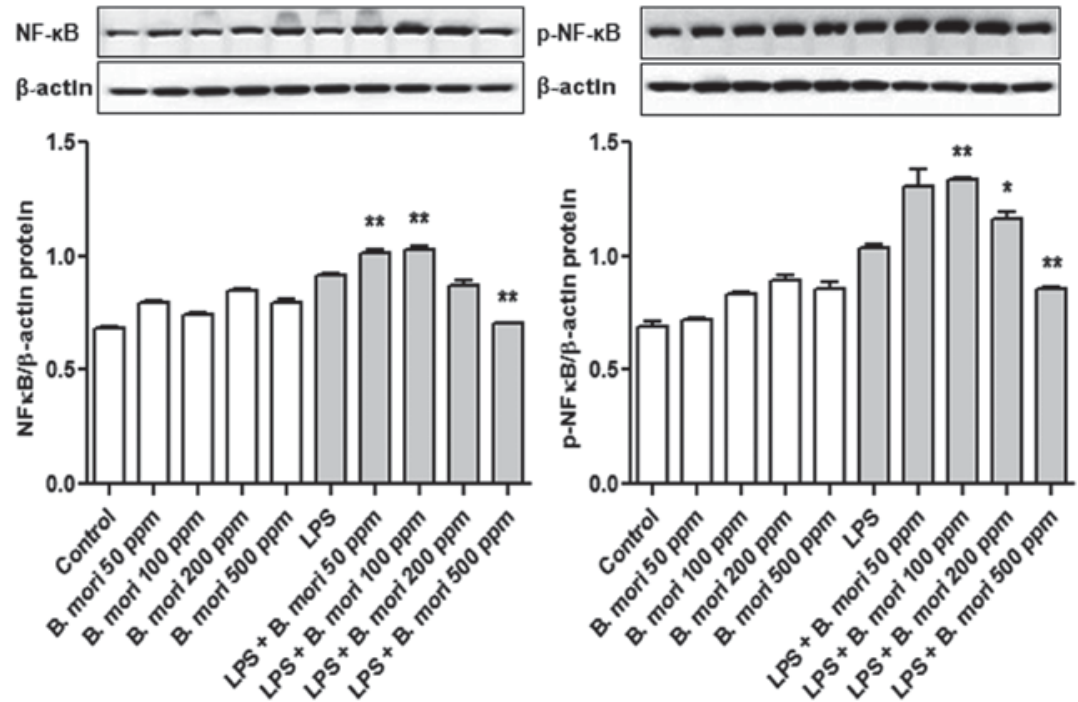

Figure 5. Effect of B. mori hemocyte extract on NF-kB p65 activity in THP 1 cells. Cells were cultured with various concentrations of freeze-dried hemocyte extract for $2 \mathrm{~h}$ and were then either left untreated or were treated with LPS for $20 \mathrm{~h}$. NFkB p65 and p-NFkB p65 protein expression was examined by western blotting. $\beta$-actin served as an internal control. The data represent the mean \pm standard error of three independent samples. ${ }^{*} \mathrm{P}<0.05$ and ${ }^{* *} \mathrm{P}<0.01$ vs. stimulation with LPS alone. NF, nuclear factor-кB; LPS, lipopolysaccharide; p, phosphorylated; B. mori, Bombyx mori.

B. mori hemocyte extract inhibits the LPS-induced increase in cytokine mRNA expression in THP-1 cells. It was then analyzed whether B. mori hemocyte extract affects inflammatory cytokine mRNA transcription using RT-qPCR. In all cases, cytokine mRNA expression increased in LPS treated cells compared with controls; the hemocyte extract suppressed the LPS-induced increases in IL-1 $\beta$, IL- 6 , IL- 8 and TNF- $\alpha$ mRNA expression in a dose-dependent manner (Fig. 4). 
B. mori hemocyte extract inhibits LPS-induced NF- $\kappa B$ p65 nuclear translocation. To investigate the mechanisms underlying inhibition of NF- $\kappa \mathrm{B}$ activity, THP-1 cells were treated with various concentrations $(0,50,100,200$ and 500 ppm) of the $B$. mori hemocyte extract. NF- $\mathrm{B}$ p 65 protein expression was determined by western blot analysis. It was identified that phosphorylation of NF- $\kappa$ B p65 in THP-1 cells treated with $500 \mathrm{ppm}$ hemocyte extract was significantly lower compared with the control (Fig. 5).

\section{Discussion}

B. mori is susceptible to bacterial infections. Its antibacterial immune proteins have been well characterized (2); several AMPs including cecropin, attacin, lebocin and moricin have been detected in $B$. mori $(11,40,41)$. AMPs are the best-known immune effectors induced by infection; they are synthesized by hemocytes, fat bodies and other tissues, and are regulated by the Toll and immune deficiency signaling pathways $(18,42,43)$. These peptides exhibit a broad spectrum of antimicrobial activity (2). A distinctive characteristic of insect antimicrobial peptides is their rapid synthesis in specific tissues and secretion into hemolymph following microbial infection $(11,13)$. In particular, hemocytes in insects serve an important role in the insect defense system (2). Hemolymph is the principle circulating fluid in insects, similar to mammalian blood; it moves through the open circulatory system and directly bathes organs and tissues (2). In the field of entomology, hemocytes are a particularly attractive area for research (3). Using the silkworm as a model, researchers have extensively studied hemocyte identification, development and differentiation, and associated cellular immune responses (3).

The present study investigated the inhibition of the inflammatory response using an extract of $B$. mori hemocytes in human monocytic leukemia cells (THP-1 cells). The $B$. mori hemocyte extract is expected to contain numerous hemocyte-derived bioactive peptides. Activation of TLR4 by LPS is known to initiate signaling events and induce the secretion of pro-inflammatory cytokines and antimicrobial peptides $(34,44)$. These proteins evoke inflammation by activating neutrophils, macrophages and dendritic cells (44). LPS stimulation has also been shown to induce the production of PGE2, IL-1 $\beta$, IL-6, TNF- $\alpha$ and other cytokines in the air-pouch inflammation model (44-46). The current study identified that the $B$. mori hemocyte extract significantly inhibited TLR4 gene transcription in THP-1 cells. These results suggest that hemocytes serve a regulatory role in inflammation at the level of TLR4 transcription. To the best of our knowledge, the modulation of LPS-activated TLRs by a hemocyte extract has not been previously reported in THP-1 cells.

The NOS and COX systems are crucial in pathophysiological conditions including inflammation and cancer $(47,48)$. In the current study, the effects of the $B$. mori hemocyte extract on the NO signaling pathway were investigated. The results revealed that $B$. mori hemocyte extract inhibited iNOS and COX-2 mRNA and protein expression. Orostachys japonicus inhibited LPS-induced proinflammatory cytokine (IL-1 $\beta$, IL-6, IL-8 and TNF- $\alpha$ ) mRNA levels in THP-1 cells (49). The present study also identified that the $B$. mori hemocyte extract suppressed the LPS-induced increase in IL-1 $\beta$, IL-6, IL-8 and TNF- $\alpha$ mRNA expression. Taken together, these findings suggest that the hemocyte extract could suppress iNOS and COX-2 at the gene transcription and translation levels in addition to suppressing the transcription of inflammatory cytokine genes in human monocytic leukemia cells.

The mechanism by which the $B$. mori hemocyte extract exerts its anti-inflammatory effects remains unclear. $\mathrm{NF}-\kappa \mathrm{B}$ has been reported to mediate the expression of numerous inflammatory genes, the products of which have been identified to be involved in tumorigenesis (47) including those encoding iNOS, COX-2, IL-1 $\beta$, IL- 6 and TNF- $\alpha(50,51)$. In the current study, the phosphorylation level of $\mathrm{p} 65$ a protein in the NF- $\kappa \mathrm{B}$ pathway was decreased by the $B$. mori hemocyte extract. This notable finding suggests that modulation of the expression of the inflammatory genes (COX-2 and iNOS) in THP-1 cells treated with hemocyte extracts was likely to be mediated through $\mathrm{NF}-\kappa \mathrm{B}$ itself.

In conclusion, the findings of the current study demonstrate that the hemocyte extract inhibited LPS-induced TLR4, cytokine and iNOS expression in human monocytic leukemia cells. Furthermore, the hemocyte extract exerted anti-inflammatory effects on LPS-activated human monocytic leukemia cells by inhibiting $\mathrm{NF}-\kappa \mathrm{B}$ activation. Further functional studies are required for an in-depth analysis of the anti-inflammatory effects of the B. mori hemocyte extract prepared in the present study.

\section{Acknowledgements}

The present study work was supported by a grant from the Next-Generation BioGreen21 Program (grant no. PJ011835), Rural Development Administration, Republic of Korea.

\section{References}

1. Kwak W, Choi JW, Ryul Kim S, Choi KH, Kim KY, Goo TW and Park SW: A novel splice variant of the decapentaplegic (dpp) gene in the wild silkworm, Bombyx mandarina. Biochem Biophys Res Commun 466: 295-299, 2015.

2. Reddy GS, Venkatappa B, Naik BJ and Rayalu DJ: Antimicrobial studies on silkworm (Bombyx mori. L) with special reference to hemolymph and hemocytes. IJAPBS 1: 39-48, 2012.

3. Liu F, Xu Q, Zhang Q, Lu A, Beerntsen BT and Ling E: Hemocytes and hematopoiesis in the silkworm, Bombyx mori. ISJ 10: 102-109, 2013.

4. Gillespie JP, Kanost MR and Trenczek T: Biological mediators of insect immunity. Annu Rev Entomol 42: 611-643, 1997.

5. Lavine MD and Strand MR: Insect hemocytes and their role in immunity. Insect Biochem Mol Biol 32: 1295-1309, 2002.

6. Strand MR: The insect cellular immune response. Insect Sci 15: $1-14,2008$

7. Kanost MR, Jiang $\mathrm{H}$ and $\mathrm{Yu} X Q$ : Innate immune responses of a lepidopteran insect, Manduca sexta. Immunol Rev 198: 97-105, 2004.

8. Liu F, Ling E and Wu S: Gene expression profiling during early response to injury and microbial challenges in the silkworm, Bombyx mori. Arch Insect Biochem Physiol 72: 16-33, 2009.

9. Jiang H, Vilcinskas A and Kanost M: Immunity in lepidopteran insects. Adv Exp Med Biol 708: 181-204, 2010.

10. Tanaka $\mathrm{H}$ and Ymamkawa M: Regulation of the innate immune responses in the silkworm, Bombyx mori. ISJ 8: 59-69, 2011.

11. Keneko Y, Furukawa S, Tanaka $\mathrm{H}$ and Yamakawa M: Expression of antimicrobial peptide genes encoding enbocin and gloverin isoforms in the silkworm, Bombyx mori. Biosci Biotechnol Biochem 71: 2233-2241, 2007.

12. Engström Y: Induction and regulation of antimicrobial peptides in Drosophila. Dev Comp Immunol 23: 345-358, 1999.

13. Hoffmann JA, Kafatos FC, Janeway CA and Ezekowitz RA: Phylogenetic perspectives in innate immunity. Science 284: 1313-1318, 1999. 
14. Hoffmann JA: The immune response of Drosophila. Nature 426 33-38, 2003.

15. Hultmark D: Drosophila immunity: Paths and patterns. Curr Opin Immunol 15: 12-19, 2003.

16. Imler JL and Bulet P: Antimicrobial peptides in Drosophila: structures, activities and gene regulation. Chem Immunol Allergy 86: 1-21, 2005.

17. Kurata S, Ariki S and Kawabata S: Recognition of pathogens and activation of immune responses in Drosophila and Horseshoe crab innate immunity. Immunobiology 211: 237-249, 2006.

18. Lemaitre B: The road to Toll. Nat Rev Immunol 4: 521-527, 2004

19. Yoon KY, Kim KJ, Youn HS, Oh SR and Lee BY: Brazilin suppresses inflammation via the down-regulation of IRAK4 in LPS-stimulated Raw264.7 macrophage. J Food Nutr Res 3 575-580, 2015.

20. Munford RS and Pugin J: Normal responses to injury prevent systemic inflammation and can be immunosuppressive. Am J Resp Crit Care 163: 316-321, 2001.

21. Mookherjee N, Brown KL, Bowdish DM, Doria S, Falsafi R, Hokamp K, Roche FM, Mu R, Doho GH, Pistolic J, et al: Modulation of the TLR-mediated inflammatory response by the endogenous human host defense peptide LL-37. J Immunol 176 2455-2464, 2006.

22. Choi YH, Kim GY and Lee HH: Anti-inflammatory effects of cordycepin in lipopolysaccharide-stimulated RAW 264.7 macrophages through Toll-like receptor 4-mediated suppression of mitogen-activated protein kinases and NF- $\mathrm{KB}$ signaling pathways. Drug Des Devel Ther 8: 1941-1953, 2014.

23. Kanno S, Shouji A, Tomizawa A, Hiura T, Osanai Y, Ujibe M Obara Y, Nakahata N and Ishikawa M: Inhibitory effect of naringin on lipopolysaccharide (LPS)-induced endotoxin shock in mice and nitric oxide production in RAW 264.7 macrophages. Life Sci 78: 673-681, 2006.

24. Poltorak A, He X, Smirnova I, Liu MY, Van Huffel C, Du X, Birdwell D, Alejos E, Silva M, Galanos C, et al: Defective LPS signaling in $\mathrm{C} 3 \mathrm{H} / \mathrm{HeJ}$ and $\mathrm{C} 57 \mathrm{BL} / 10 \mathrm{ScCr}$ mice: Mutations in Tlr4 gene. Science 282: 2085-2088, 1998.

25. Zhang X, Wang J, Qian W, Zhao J, Sun L, Qian Y and Xiao H: Dexmedetomidine inhibits tumor necrosis factor-alpha and interleukin 6 in lipopolysaccharide-stimulated astrocytes by suppression of c-Jun N-terminal kinases. Inflammation 37 942-949, 2014

26. Sato S, Takeuchi O, Fujita T, Tomizawa H, Takeda $K$ and Akira S: A variety of microbial components induce tolerance to lipopolysaccharide by differentially affecting MyD88-dependent and-independent pathways. Int Immunol 14: 783-791, 2002.

27. Choi Y, Lee MK, Lim SY, Sung SH and Kim YC: Inhibition of inducible NO synthase, cyclooxygenase-2 and interleukin-1beta by torilin is mediated by mitogen-activated protein kinases in microglial BV2 cells. Br J Pharmacol 156: 933-940, 2009.

28. Pocivavsek A, Bums MP and Rebeck GW: Low-density lipoprotein receptors regulate microglial inflammation through c-Jun N-terminal kinase. Glia 57: 444-453, 2009.

29. Gorina R, Santalucia T, Petegnief V, Ejarque-Ortiz A, Saura J and Planas AM: Astrocytes are very sensitive to develop innate immune responses to lipid-carried short interfering RNA. Glia 57: 93-107, 2009.

30. Zhang X, Feng J, Zhu P and Zhao Z: Ketamine inhibits calcium elevation and hydroxyl radical and nitric oxide production in lipopolysaccharide-stimulated NR8383 alveolar macrophages. Inflammation 36: 1094-1100, 2013.

31. Anwar MA, Basith S and Choi S: Negative regulatory approaches to the attenuation of Toll-like receptor signaling. Exp Mol Med 45: e11, 2013.

32. Takeda K, Kaisho T and Akira S: Toll-like receptors. Annu Rev Immunol 21: 335-376, 2003.

33. Van der Mark VA, Ghiboub M, Marsman C, Zhao J, Van Dijk R, Hiralall JK, Ho-Mok KS, Castricum Z, de Jonge WJ, Oude Elferink RP and Paulusma CC: Phospholipid flippases attenuate LPS-induced TLR4 signaling by mediating endocytic retrieval of Toll-like receptor 4. Cell Mol Life Sci 74: 715-730, 2017.

34. Kawai T and Akira S: The role of pattern-recognition receptors in innate immunity: Update on Toll-like receptors. Nat Immunol 11: $373-384,2010$
35. Chan ED and Riches DW: IFN-gamma + LPS induction of iNOS is modulated by ERK, JNK/SAPK, and p38(mapk) in a mouse macrophage cell line. Am J Physiol Cell Physiol 280: C441-C450, 2001.

36. Hattori Y, Hattori S and Kasai K: Lipopolysaccharide activates Akt in vascular smooth muscle cells resulting in induction of inducible nitric oxide synthase through nuclear factor-kappa B activation. Eur J Pharmacol 481: 153-158, 2003.

37. Poltorak A, Ricciardi-Castagnoli P, Citterio S and Beutler B: Physical contact between lipopolysaccharide and Toll-like receptor 4 revealed by genetic complementation. Proc Natl Acad Sci USA 97: 2163-2167, 2000.

38. Lee CC, Avalos AM and Ploegh HL: Accessory molecules for Toll-like receptors and their function. Nat Rev Immunol 12: $168-179,2012$.

39. Livak KJ and Schmittgen TD: Analysis of relative gene expression data using real-time quantitative PCR and the 2(-Delta Delta C(T)) method. Methods 25: 402-408, 2001.

40. Hara S and Yamakawa M: Moricin, a novel type of antibacterial peptide isolated from the silkworm, Bombyx mori. J Bio Chem 270: 29923-29927, 1995.

41. Hara S and Yamakawa M: A novel antibacterial peptide family isolated from the silkworm, Bombyx mori. Biochem J 310: 651-656, 1995

42. Yang J, Wang X, Tang S, Shen Z and Wu J: Peptidoglycan recognition protein $\mathrm{S} 2$ from silkworm integument: Characterization, microbe-induced expression, and involvement in the immune-deficiency pathway. J Insect Sci 15: pii 20, 2015.

43. Bulet P, Hetru C, Dimarcq JL and Hoffmann D: Antimicrobial peptides in insects; structure and function. Dev Comp Immunol 23: 329-344, 1999.

44. Asakawal S, Kishimotol Y, Takanol T, Okital K, Takakuwa S, Sato T, Hiratsuka M, Takeuchi O and Hirasawa N: Nickel ions selectively inhibit lipopolysaccharide-induced interleukin-6 production by decreasing its mRNA stability. PLoS One 10: e0119428, 2015.

45. Kamachi F, Ban HS, Hirasawa N and Ohuchi K: Inhibition of lipopolysaccharide-induced prostaglandin E2 production and inflammation by the $\mathrm{Na}+\mathrm{H}+$ exchanger inhibitors. J Pharmacol Exp Ther 321: 345-352, 2007.

46. Antoine F, Simard JC and Girard D: Curcumin inhibits agent-induced human neutrophil functions in vitro and lipopolysaccharide-induced neutrophilic infiltration in vivo. Int Immunopharmacol 17: 1101-1107, 2013

47. Kim YI, Park SW, Yoon YK, Lee KW, Lee JH, Woo HJ and Kim Y: Orostachys japonicus inhibits the expression of MMP-2 and MMP-9 mRNA and modulates the expression of iNOS and COX-2 genes in human PMA-differentiated THP-1 cells via inhibition of NF- $\kappa \mathrm{B}$ and MAPK activation. Mol Med Rep 12: 657-662, 2015 .

48. Ohshima H, Tazawa H, Sylla BS and Sawa T: Prevention of human cancer by modulation of chronic inflammatory processes. Mutat Res 591: 110-122, 2005.

49. Yoon YK, Woo HJ and Kim Y: Orostachys japonicus inhibits expression of the TLR4, NOD2, iNOS and COX-2 genes in LPS-stimulated human PMA-differentiated THP-1 cells by inhibiting NF- $\kappa$ B and MAPK activation. Evid Based Complement Alternat Med 2015: 682019, 2015.

50. Kim YI, Park SW, Kang IJ, Shin MK and Lee MH: Activin suppresses LPS-induced Toll-like receptor, cytokine and inducible nitric oxide synthase expression in normal human melanocytes by inhibiting NF- $\kappa$ B and MAPK pathway activation. Int J Mol Med 36: 1165-1172, 2015.

51. Wan F and Lenardo MJ: The nuclear signaling of NF-kappaB: Current knowledge, new insights, and future perspectives. Cell Res 20: 24-33, 2010. 